\title{
HUBUNGAN PROFIL LIPID DENGAN LAMA RAWATAN PASIEN STROKE ISKEMIK DI BADAN LAYANAN UMUM DAERAH RUMAH SAKIT UMUM CUT MEUTIA KABUPATEN ACEH UTARA
}

\author{
Amelia Intan Saputri ${ }^{1}$, Meutia Maulina $^{2^{*}}$ \\ ${ }^{1}$ Mahasiswa Program Studi Pendidikan Dokter Fakultas Kedokteran Universitas Malikussaleh \\ 2Bagian Histologi Fakultas Kedokteran Universitas Malikussaleh Jl. H. Meunasah, Uteunkot, \\ Cunda, Lhokseumawe, Provinsi Aceh, 24351 \\ *Corresponding Author : meutia.maulina@unimal.ac.id
}

\begin{abstract}
Abstrak
Stroke merupakan penyebab kematian ketiga di dunia dan merupakan penyebab kematian utama dengan peningkatan prevalensi yang signifikan setiap tahunnya di Indonesia. Stroke iskemik sering disebabkan kelainan profil lipid darah yaitu peningkatan LDL, trigliserida dan kolesterol total serta penurunan HDL. Tingginya kadar LDL, trigliserida dan kolesterol total menyebabkan kelainan pada pembuluh darah sehingga menjadi salah satu faktor risiko penyebab stroke iskemik yang berpengaruh pada keluaran setelah serangan stroke. Kadar HDL yang rendah setelah serangan stroke akan mengakibatkan hambatan pemulihan dan peningkatan mortalitas. Tujuan dari penelitian ini adalah menganalisis hubungan antara profil lipid dengan lama rawatan pasien stroke iskemik. Penelitian ini merupakan penelitian observasional analitik dengan pendekatan cross sectional. Analisis data menggunakan analisis univariat dan bivariat dengan uji korelasi Pearson. Penelitian ini dilaksanakan di BLUD RSU Cut Meutia Kabupaten Aceh Utara menggunakan teknik total sampling. Sampel penelitian ini berjumlah 98 pasien. Rata-rata kadar profil lipid pasien saat mulai dirawat adalah LDL: $155,70 \mathrm{mg} / \mathrm{dL}$, HDL 44,04mg/dL, trigliserida 152,13 mg/dL dan kolesterol total $232,74 \mathrm{mg} / \mathrm{dL}$. Rata-rata lama perawatan pasien di rumah sakit adalah 5 hari. Terdapat hubungan antara kadar LDL $(\mathrm{r}=0,275 ; p<0,01)$, kadar HDL $(\mathrm{r}=-0,292$; $p<0,01)$ dan kolesterol total $(\mathrm{r}=0,344 ; p<0,01)$ dengan lama rawatan pasien stroke iskemik, dan tidak terdapat hubungan antara kadar trigliserida dengan lama rawatan pasien stroke iskemik $(\mathrm{r}=0,169 ; \mathrm{p}>0,01)$. Penelitian ini menyimpulkan bahwa semakin tinggi kadar LDL dan kolesterol total serta semakin rendah kadar HDL saat mulai dirawat maka lama rawatan semakin panjang.
\end{abstract}

Kata Kunci : stroke iskemik; LDL; HDL; trigliserida; kolesterol total; lama rawatan 


\title{
CORRELATION BETWEEN LIPID PROFILE WITH THE TREATMENT DURATION OF ISCHEMIC STROKE PATIENTS AT BADAN LAYANAN UMUM DAERAH RUMAH SAKIT UMUM CUT MEUTIA NORTH ACEH DISTRICT
}

\begin{abstract}
Stroke is the third deadliest cause of death in the world, while in Indonesia, stroke is the number one with the significant increase of prevalence each year. Ischemic stroke is often caused by abnormal blood lipid profile which is the increase of LDL, triglycerides and total cholesterol, also the decrease of HDL. The increasing of LDL, triglycerides, and total cholesterol are the causes an anomaly in the veins which becomes a risk factor causing the ischemic stroke. This risk factor would have an impact on the stroke output. The low HDL level after stroke will cause the recovery inhibition and the increase of mortality. This research aims to determine the relationship between lipid profile and treatment duration of ischemic stroke patients. This research is an analytic observasional research with cross sectional approach. This research is conducted at BLUD RSU Cut Meutia, North Aceh. Data analysis used univariate and bivariate analysis with Pearson correlation test. This research sample consists of 98 patients. The average lipid profile level when then starting the treatment are, LDL: 155,70 mg/dL, HDL: 44,04 mg/dL, triglycerides: $152,13 \mathrm{mg} / \mathrm{dL}$, and total cholesterol $232,74 \mathrm{mg} / \mathrm{dL}$. The average treatment duration in the hospital is 5 days. There was a correlation between LDL level $(r=0,275$; $\mathrm{p}<0,01)$, HDL level $(\mathrm{r}=-0,292 ; \mathrm{p}<0,01)$ and total cholesterol $(\mathrm{r}=0,344 ; \mathrm{p}<0,01)$ with the treatment duration of ischemic stroke patients and there was no correlation between triglycerides level with the treatment duration of ischemic stroke patients $(r=0,169 ; p>0,01)$. This study concluded that the higher of LDL and total cholesterol levels and lower HDL level at the start of treatment cause treatment duration was getting longer.
\end{abstract}

Keyword: ischemic stroke; LDL; HDL; triglycerides; total cholesterol; treatment duration 


\section{Pendahuluan}

Stroke merupakan masalah utama kesehatan di negara maju dan berkembang serta penyebab utama kecacatan pada orang dewasa. World Health Organization (WHO) mendefinisikan stroke sebagai gangguan peredaran darah otak yang terjadi secara mendadak dengan tanda klinis gangguan neurologis fokal atau terkadang global, berlangsung lebih dari 24 jam serta dapat menimbulkan kematian. ${ }^{1}$ Stroke menempati posisi ketiga sebagai penyebab kematian tertinggi serta memiliki prevalensi 30,7 juta penduduk dan insidensi 9 juta per tahun di dunia. Sekitar 795.000 orang di Amerika Serikat terserang stroke setiap tahunnya dan 610.000 diantaranya merupakan serangan stroke pertama sedangkan 185.000 merupakan stroke berulang. ${ }^{2,3}$

Stroke selalu masuk dalam 4 besar penyebab kematian tertinggi diantara negara-negara Asia Tenggara sejak tahun 1992. Prevalensi kejadiannya adalah 4,5 juta dengan insidensi 1,8 juta per tahun. ${ }^{4}$ Menurut WHO, Indonesia telah menempati peringkat ke-97 dunia untuk jumlah penderita stroke terbanyak dengan jumlah angka kematian mencapai 138.268 orang atau $9,7 \%$ dari total kematian yang terjadi pada tahun 2011. ${ }^{5}$ Hasil Riset Kesehatan Dasar (Riskesdas) pada tahun 2007, stroke merupakan penyebab kematian utama di Indonesia dengan insidensi stroke 8,3 per 1.000 penduduk dan mengalami peningkatan insidensi menjadi 12,1 per 1.000 penduduk pada hasil Riskesdas tahun 2013. Prevalensi yang tertinggi ialah Provinsi Sulawesi Selatan dengan insidensi 17,9 per 1.000 penduduk, kemudian disusul Daerah Istimewa Yogyakarta dengan insidensi 16,9 per 1.000 penduduk dan Sulawesi Tengah dengan insidensi 16,6 per 1.000 penduduk. Aceh menempati urutan ke-17 sebesar 10,5 per 1.000 penduduk dengan insidensi tertinggi terdapat di Kota Sabang yaitu 29,8 per 1.000 penduduk, diikuti Kota
Lhokseumawe 19,2 per 1.000 penduduk dan Bireun sebanyak 18,2 per 1.000 penduduk. ${ }^{6}$

Stroke terdiri dari 2 jenis, yaitu stroke iskemik dan stroke hemoragik. Stroke iskemik disebabkan oleh trombus atau embolus, sedangkan stroke hemoragik terjadi akibat pecahnya pembuluh darah yang menyebabkan perdarahan intraserebral atau ruang subaraknoid7. Stroke yang dominan terjadi adalah stroke iskemik dengan prevalensi sebanyak $83 \%$ dari keseluruhan stroke dan $17 \%$ sisanya merupakan stroke hemoragik. ${ }^{2}$

Stroke iskemik disebabkan karena adanya kelainan profil lipid darah yang utama yaitu kenaikan kadar kolesterol total, trigliserida, Low Density Lipoprotein (LDL) serta penurunan kadar High Density Lipoprotein (HDL). Keempat profil lipid tersebut memiliki peranan penting, karena peningkatan trigliserida berakibat buruk pada pembuluh darah, peningkatan kolesterol berakibat penyumbatan pada pembuluh darah, peningkatan LDL berakibat pada penyempitan pembuluh darah serta penurunan HDL menyebabkan HDL tidak dapat membersihkan pembuluh darah dari berbagai endapan yang disebabkan oleh ketiga profil lipid lainnya. ${ }^{8}$ Tingginya kadar LDL tidak hanya sebagai faktor risiko penyebab stroke iskemik, tetapi juga berpengaruh pada keluaran setelah serangan stroke, selain hipertensi, hiperglikemia, hipertemia, usia lanjut dan keparahan stroke. ${ }^{4}$

Penelitian epidemiologi menghubungkan peningkatan risiko stroke pada pasien dengan rasio kolesterol total terhadap HDL yang tinggi. Risiko stroke akan meningkat sebesar 25\% karena peningkatan $1 \mathrm{mmol} / \mathrm{L}$ $(38,7 \mathrm{mg} / \mathrm{dL})$ kadar kolesterol darah total sedangkan risiko stroke akan menurun sebesar $47 \%$ pada setiap peningkatan 1 mmol/L kadar HDL. ${ }^{9}$ Sejalan dengan pendapat di atas, pada 492 pasien stroke iskemik menunjukkan bahwa kadar LDL kolesterol dan kolesterol total yang tinggi 
meningkatkan risiko stroke sampai dua kali lipat dibandingkan dengan orang yang kadar LDL dan kolesterol totalnya normal. ${ }^{10}$ Annals of Neurology juga menyatakan bahwa peningkatan kadar trigliserida meningkatkan risiko stroke iskemik pada pria dan wanita. ${ }^{11}$ Kadar HDL yang rendah setelah serangan stroke akan mengakibatkan hambatan pemulihan dan peningkatan mortalitas. ${ }^{12}$ Hambatan pemulihan akan mengakibatkan lama perawatan pasien stroke iskemik bertambah. Hal ini berhubungan dengan peran HDL yang memberi efek stabilisasi dan regresi plak serta proteksi terhadap oksidasi LDL.

Penelitian yang spesifik menghubungkan antara profil lipid dengan lama rawatan belum banyak dilakukan. Thaib (2008) menyatakan bahwa semakin tinggi kadar LDL kolesterol saat pertama dirawat, semakin panjangnya lama perawatan pada pasien stroke iskemik yang pulang hidup, tetapi belum ada penelitian lain yang menghubungkan antara kolesterol total, trigliserida dan HDL dengan lama rawatan pasien stroke iskemik. ${ }^{13}$ Penelitian mengenai hubungan profil lipid dengan lama rawatan pasien stroke iskemik di Badan Layanan Umum Daerah Rumah Sakit Umum Cut Meutia Kabupaten Aceh Utara belum pernah dilakukan, oleh karena itu perlu dikaji tentang hubungan profil lipid dengan lama perawatan pasien stroke iskemik di Badan Layanan Umum Daerah Rumah Sakit Umum Cut Meutia Kabupaten Aceh Utara.

\section{Metode}

\section{Jenis dan Waktu Penelitian}

Penelitian ini merupakan penelitian observasional analitik dengan desain cross sectional. Penelitian ini dilaksanakan di di Badan Layanan Umum Daerah Rumah Sakit Umum Cut Meutia Kabupaten Aceh Utara. Penelitian ini dilaksanakan pada bulan September 2015 sampai Februari 2016.

\section{Populasi dan Sampel Penelitian}

Populasi dalam penelitian ini pasien stroke iskemik yang dirawat di Badan Layanan Umum Daerah Rumah Sakit Umum Cut Meutia Kabupaten Aceh Utara tahun 2015 sebanyak 212 pasien.

Pengambilan sampel dilakukan dengan teknik total sampling berdasarkan kriteria inklusi dan eksklusi, sehingga diperoleh sampel sebanyak 98 lansia.

Kriteria inklusi berupa pasien stroke iskemik dengan onset maksimal 72 jam pertama, mengalami serangan stroke pertama kali dan memiliki data rekam medik lengkap dengan hasil pemeriksaan laboratorium profil lipid darah saat mulai dirawat. Kriteria eksklusi berupa pasien yang mengalami 2 jenis stroke yaitu stroke iskemik dan hemoragik, pasien yang pulang dari rumah sakit bukan atas indikasi dokter melinkan atas paksaan pasien atau keluarga pasien, pasien yang keluar dari rumah sakit dalam keadaan meninggal dan pasien dengan penyakit penyerta lain kecuali hipertensi.

\section{Cara Pengumpulan Data}

Data yang dikumpulkan pada penelitian ini adalah data sekunder berdasarkan rekam medik pasien berupa diagnosis stroke iskemik, hasil pemeriksaan profil lipid darah yaitu kadar kolesterol total, trigliserida, LDL dan HDL, serta lama rawatan pasien di rumah sakit.

\section{Analisis Data}

Data dianalisis secara univariat dan bivariat. Analisis univariat digunakan untuk mengetahui karakteristik sebaran data yaitu mean, modus, median dan standar deviasi pasien stroke iskemik di Badan Layanan Umum Daerah Rumah Sakit Umum Cut Meutia Kabupaten Aceh Utara berdasarkan usia, jenis kelamin, profil lipid dan lama rawatan. Analisis bivariat digunakan untuk menguji hipotesis hubungan profil lipid 
dengan lama rawatan pasien stroke iskemik menggunakan uji korelasi pearson.
Hasil Penelitian

Karakteristik Pasien Stroke Iskemik

a. Usia

Hasil penelitian dari 98 pasien stroke iskemik diperoleh data usia sebagai berikut:

Tabel 1. Distribusi usia pasien stroke iskemik di BLUD RSU Cut Meutia

\begin{tabular}{lccccc}
\hline Karakteristik & Rerata & SD & Median & Minimal & Maksimal \\
\hline Usia (tahun) & 59,50 & 13,34 & 60 & 27 & 90 \\
\hline
\end{tabular}

Sumber: Data sekunder, 2015

Pasien stroke iskemik yang dirawat di BLUD RSU Cut Meutia Kabupaten Aceh Utara tahun 2015 memiliki karakteristik usia rata-rata 59,50 tahun, median 60 tahun, standar deviasi sebesar 13,34 tahun dan insiden stroke iskemik terjadi pada usia 2790 tahun.

b. Jenis kelamin

Hasil penelitian dari 98 pasien stroke iskemik diperoleh data jenis kelamin sebagai berikut:

Tabel 2. Distribusi jenis kelamin pasien

stroke iskemik di BLUD RSU Cut Meutia

\begin{tabular}{lcc}
\hline $\begin{array}{l}\text { Jenis } \\
\text { Kelamin }\end{array}$ & $\begin{array}{c}\text { Jumlah } \\
\text { (n) }\end{array}$ & $\begin{array}{c}\text { Persentase } \\
(\mathbf{\%})\end{array}$ \\
\hline Laki-laki & 62 & 63,3 \\
Perempuan & 36 & 36,7 \\
\hline Total & 98 & 100
\end{tabular}

Sumber: Data sekunder, 2015

Tabel 3. Karakteristik profil lipid pasien stroke iskemik di BLUD RSU Cut Meutia

\begin{tabular}{lccccc}
\hline Profil Lipid (mg/dL) & Rerata & Median & SD & Minimal & Maksimal \\
\hline LDL & 155,70 & 146 & 51,158 & 58 & 290 \\
HDL & 44,04 & 44 & 9,173 & 23 & 65 \\
Trigliserida & 152,13 & 138 & 79,766 & 53 & 486 \\
Kolesterol total & 232,74 & 233 & 57,399 & 116 & 395 \\
\hline
\end{tabular}

Sumber: Data sekunder, 2015

Rata-rata kadar profil lipid pasien stroke iskemik di BLUD RSU Cut Meutia tahun 2015 yaitu LDL sebesar 155,70 mg/ dL (batas tinggi), HDL 44,04 mg/dL (sedang), trigliserida $152,13 \mathrm{mg} / \mathrm{dL}$ (batas tinggi) dan kolesterol total $232,74 \mathrm{mg} / \mathrm{dL}$ (sedang).
Distribusi karakteristik jenis kelamin pasien stroke iskemik di BLUD RSU Cut Meutia Kabupaten Aceh Utara tahun 2015 terbanyak adalah laki-laki berjumlah 62 orang $(63,3 \%)$ dan perempuan 36 orang $(36,7 \%)$.

\section{Profil Lipid Pasien Stroke Iskemik \\ Hasil penelitian dari 98 pasien stroke iskemik diperoleh data profil lipid sebagai berikut:}


HDL 23-65 mg/dL, trigliserida 53-486 $\mathrm{mg} / \mathrm{dL}$ dan kolesterol total 116-395 mg/dL.
Lama Rawatan Pasien Stroke Iskemik

Hasil penelitian dari 98 pasien stroke iskemik diperoleh data lama rawatan sebagai berikut:

Tabel 4. Karakteristik lama rawat pasien stroke iskemik di BLUD RSU Cut Meutia

\begin{tabular}{lccccc}
\hline & Rerata & Median & SD & Minimal & Maksimal \\
\hline Lama rawat (hari) & 5,32 & 5,00 & 1,564 & 3 & 9 \\
\hline
\end{tabular}

Sumber: Data sekunder, 2015

Rata-rata lama rawat pasien stroke iskemik di BLUD RSU Cut Meutia tahun 2015 adalah 5 hari, median 5 hari dan rentang lama rawat pasien stroke iskemik di penelitian ini adalah 3-9 hari.

\section{Hubungan Profil Lipid dengan Lama Rawatan}

Data yang telah dikumpulkan berupa rerata profil lipid dan lama rawatan pasien stroke iksemik selanjutnya dianalisis secara statistik dengan menggunakan uji korelasi Pearson. Sebelum dilakuakan analisis, dilakukan uji normalitas data rerata profil lipid dan lama rawatan dengan uji Kolmogorov-smirnov. Hasil uji normalitas dapat dilihat pada tabel 5 .

Tabel 5. Uji normalitas data pasien stroke iskemik di BLUD RSU Cut Meutia Kabupaten Aceh Utara

\begin{tabular}{lcc}
\hline Variabel & $\begin{array}{c}\text { Uji Kolmogorov- } \\
\text { smirnov }\end{array}$ & $\mathbf{p}$ \\
\hline LDL & 0,969 & 0,276 \\
HDL & 0,864 & 0,357 \\
Trigliserida & 1,536 & 0,041 \\
Kolesterol total & 0,434 & 0,969 \\
Lama rawat & 2,309 & 0,000 \\
\hline Sumber: Data sekunder, 2015 &
\end{tabular}

Uji normalitas data profil lipid yang dilakukan pada pasien stroke iskemik di BLUD RSU Cut Meutia, didapatkan nilai signifikansi data LDL ( $\mathrm{p}$ value) 0,276 $(\mathrm{p}>0,01)$, HDL 0,357 ( $\mathrm{p}>0,01)$, trigliserida $0,041(p>0,01)$ dan kolesterol total 0,969 $(p>0,01)$ sehingga dapat disimpulkan bahwa data profil lipid berdistribusi normal. Uji normalitas data lama rawat yang dilakukan pada pasien stroke iskemik di BLUD RSU Cut Meutia, didapatkan nilai signifikansi $\quad(p$ value $) \quad 0,000 \quad(p<0,01)$ sehingga dapat disimpulkan bahwa data lama rawat tidak berdistribusi normal.

Syarat penggunaan uji korelasi pearson terpenuhi sehingga analisis hubungan profil lipid dengan lama rawat pasien stroke iskemik di BLUD RSU Cut Meutia menggunakan uji korelasi pearson dengan convidence interval 99\% (derajat kemaknaan $0,01)$. Hasil uji korelasi pearson dapat dilihat pada tabel 6 .

Tabel 6. Uji korelasi Pearson profil lipid dengan lama rawat pasien stroke iskemik

\begin{tabular}{lcc}
\hline Profil Lipid & r & P \\
\hline LDL & 0,275 & 0,006 \\
HDL & $-0,292$ & 0,004 \\
Trigliserida & 0,169 & 0,096 \\
Kolesterol total & 0,344 & 0,001 \\
\hline
\end{tabular}

Sumber: Data sekunder, 2015

Hasil uji statistik hubungan profil lipid berupa LDL, HDL dan kolesterol total dengan lama rawatan pasien stroke iskemik diperoleh nilai signifikansi ( $\mathrm{p}$ value) $>0,05$ yang berarti $\mathrm{H}_{0}$ ditolak sehingga terdapat hubungan antara LDL, HDL dan kolesterol total dengan lama rawatan pasien stroke iskemik di BLUD RSU Cut Meutia Kabupaten Aceh Utara.

Hasil uji statistik hubungan profil lipid trigliserida dengan lama rawatan diperoleh nilai signifikansi ( $\mathrm{p}$ value) sebesar 0,096 
( $\mathrm{p}>0,01)$ yang berarti $\mathrm{H}_{0}$ diterima sehingga tidak terdapat hubungan antara kadar trigliserida dengan lama rawatan pasien stroke iskemik di BLUD RSU Cut Meutia Kabupaten Aceh Utara.

Kekuatan hubungan yang positif didapatkan pada hasil uji statistik LDL dan kolesterol total menunjukkan bahwa semakin tinggi kadar profil lipid saat mulai dirawat maka lama rawatan semakin panjang. Kekuatan hubungan yang negatif pada hasil uji statistik HDL menunjukkan bahwa semakin rendah kadar HDL saat mulai dirawat maka lama rawatan semakin panjang.

\section{Pembahasan}

\section{Karakteristik Pasien Stroke Iskemik}

Hasil penelitian yang didapatkan dari 98 pasien, rata-rata usia terserang stroke adalah 59,50 tahun dengan insiden stroke iskemik terjadi pada usia 27-89 tahun. Stroke dapat terjadi pada usia berapa saja bahkan pada usia muda sekalipun bila dilihat dari berbagai kelainan yang menjadi pencetus serangan stroke, seperti aneurisma intrakranial, malformasi vaskular otak dan kelainan jantung bawaan. ${ }^{14}$

Stroke umumnya terjadi pada golongan umur lebih tua. Hal ini disebabkan karena stroke merupakan penyakit yang terjadi akibat gangguan aliran pada pembuluh darah. Pembuluh darah orang yang lebih tua cenderung mengalami perubahan secara degeneratif dan mulai terlihat hasil dari proses aterosklerosis. Cepat atau lambatnya proses aterosklerosis yang dapat menjadi pencetus stroke tergantung dari gaya hidup sehat dan perilaku makan. Heart and Stroke Foundation (2010) menemukan bahwa 1 dari 5 orang yang berumur 50 sampai 64 tahun memiliki 2 atau lebih faktor risiko untuk terserang stroke dan penyakit jantung yaitu tekanan darah tinggi, obesitas, diabetes melitus dan merokok. Kombinasi dari berbagai faktor risiko tersebut memperbesar risiko untuk terserang stroke pada golongan umur di atas 50 tahun. ${ }^{15}$

Hasil penelitian ini sejalan dengan penelitian Yanis (2004) bahwa stroke iskemik lebih sering terjadi pada usia 59,05 tahun. ${ }^{16}$ Agustina (2009) melaporkan di RSUP Fatmawati Jakarta Selatan didapatkan pasien stroke iskemik terbanyak pada kelompok usia 45-64 tahun. ${ }^{17}$ Penelitian yang dilakukan oleh Nastiti (2012) di RS Kratau Medika Banten, didapatkan bahwa stroke iskemik lebih sering ditemukan pada kelompok usia 51-65 tahun. 18

Berdasarkan jenis kelamin, kejadian stroke iskemik pada penelitian ini lebih banyak ditemukan pada laki-laki, yaitu berjumlah 62 pasien $(63,3 \%)$, sedangkan perempuan 36 pasien $(36,7 \%)$. Stroke lebih sering ditemukan pada pria dibanding wanita. Hal ini disebabkan adanya hormon estrogen yang dimiliki wanita sebelum menopause yang berfungsi sebagai proteksi pembuluh darah terhadap proses aterosklerosis yang merupakan penyebab tersering stroke thrombus. ${ }^{19}$

Estrogen akan meningkatkan kadar kolesterol HDL dan menurunkan kadar kolesterol LDL. Kolesterol LDL akan menimbulkan plak di dalam darah tetapi kadar kolesterol HDL yang tinggi akan membantu membersihkan plakplak yang mulai menempel. Estrogen juga berperan sebagai antioksidan. Peranan estrogen sebagai antioksidan adalah mencegah proses oksidasi LDL sehingga kemampuan LDL untuk menembus plak akan berkurang. Peranan estrogen yang lain disamping sebagai pembentuk ciri sekunder wanita adalah sebagai vasodilator pembuluh darah jantung sehingga aliran darah menjadi lancar dan jantung memperoleh suplai oksigen secara cukup. ${ }^{20}$

Hasil penelitian ini sejalan dengan beberapa penelitian sebelumnya yang melaporkan stroke iskemik lebih banyak ditemukan pada laki-laki dibandingkan 
perempuan. Penelitian yang dilakukan oleh Agustina (2009) di RSUP Fatmawati Jakarta Selatan, didapatkan stroke iskmeik ditemukan pada 73 pasien laki-laki (61,3\%) dan 46 pasien perempuan $(38,7 \%) \cdot{ }^{17}$ Handayani (2013) melaporkan 62 pasien $(68,9 \%)$ berjenis kelamin laki-laki dan 28 pasien $(31,1 \%)$ berjenis kelamin perempuan mengalami stroke iskmeik di RSUP Dr. Kariadi Semarang. ${ }^{21}$ Hasil penelitian Nastiti (2012) menyatakan bahwa penderita stoke iskemik di RS Krakatau Medika Banten berjumlah 102 pasien (67\%) berjenis kelamin laki-laki dan 50 pasien $(33 \%)$ berjenis kelamin perempuan. ${ }^{18}$

\section{Hubungan LDL dengan lama rawatan pasien}

Hasil uji statistik diperoleh nilai signifikansi ( $\mathrm{p}$ value) sebesar $0,006(\mathrm{p}<0,01)$ yang berarti $\mathrm{H}_{0}$ ditolak sehingga terdapat hubungan antara kadar LDL dengan lama rawatan pasien stroke iskemik di BLUD RSU Cut Meutia Kabupaten Aceh Utara.

Kadar LDL darah dapat meningkat setelah serangan stroke iskemik disertai dengan Fractional Catabolic Rate (FCR) LDL menurun sedangkan FCR HDL meningkat yang pada akhirnya akan berakibat kadar LDL darah semakin meningkat. Low Density Lipoprotein bersifat aterogenik yang akan mengakibatkan semakin terbentuknya plak aterosklerosis atau plak tersebut tidak akan berkurang dalam waktu yang singkat karena plak aterosklerosis yang sudah terbentuk cenderung menjadi keras dan akan sulit untuk mengalami regresi. ${ }^{22}$ Semua hal tersebut akan mengakibatkan terjadinya disfungsi mekanisme vasoregulasi yang akan berhubungan dengan peningkatan morbiditas setelah serangan stroke serta peningkatan lama rawatan pasien..$^{23}$

Hasil penelitian ini sesuai dengan penelitian yang dilakukan oleh Thaib (2008) di RS. Dr. Kariadi Semarang yang didapatkan bahwa secara signifikan terdapat korelasi antara kadar LDL darah pada stroke iskemik dengan lama perawatan pada pasien yang pulang hidup. ${ }^{13}$

\section{Hubungan HDL dengan lama rawatan pasien}

Hasil uji statistik diperoleh nilai signifikansi ( $\mathrm{p}$ value) sebesar $0,004(\mathrm{p}<0,01)$ yang berarti $\mathrm{H}_{0}$ ditolak sehingga terdapat hubungan antara kadar HDL dengan lama rawatan pasien stroke iskemik di BLUD RSU Cut Meutia Kabupaten Aceh Utara.

Newman et al., (2007) mengatakan bahwa kadar HDL yang rendah setelah serangan stroke akan mengakibatkan hambatan pemulihan. Terhambatnya proses pemulihan akan menyebabkan masa perawatan yang lama. ${ }^{12}$ Kadar HDL yang rendah akan menyebabkan penurunan efek stabilisasi dan regresi plak serta berkurangnya proteksi terhadap oksidasi LDL, sehingga proses inflamasi dan aterosklerosis akan meningkat ${ }^{1}$. Hasil penelitian tersebut juga didukung oleh Sohail et al., (2013) yang menyatakan pasien stroke dengan kadar HDL yang rendah memiliki keparahan stroke yang besar dan luaran klinis yang buruk. ${ }^{24}$ Saribanon (2011) juga melaporkan dalam penelitiannya bahwa terdapat hubungan antara kadar HDL dengan kejadian mortalitas pasien stroke iskemik. ${ }^{25}$

\section{Hubungan trigliserida dengan lama rawatan pasien}

Hasil uji statistik diperoleh nilai signifikansi ( $p$ value) sebesar $0,096(p>0,01)$ yang berarti $\mathrm{H}_{0}$ diterima sehingga tidak terdapat hubungan antara kadar trigliserida dengan lama rawatan pasien stroke iskemik di BLUD RSU Cut Meutia Kabupaten Aceh Utara.

Tidak terdapatnya hubungan trigliserida dengan lama rawatan pasien 
stroke iskemik pada penelitian ini dapat disebabkan karena kadar trigliserida yang berlebih di dalam darah akan dipecah oleh hati menjadi LDL. 22 Peningkatan kadar trigliserida juga membuat kolesterol LDL bersifat toksik pada dinding arteri dan mengurangi efek menguntungkan HDL. ${ }^{26}$ Hal ini mungkin yang menyebabkan tidak terdapat hubungan antara trigliserida dengan lama rawatan pasien stroke iskemik.

Tingginya trigliserida dikaitkan dengan peningkatan faktor resiko stroke iskemik 3 hingga 4 kali lipat. ${ }^{27}$ Varbo et al., (2011) menyatakan bahwa peningkatan kadar trigliserida meningkatkan risiko stroke iskemik pada pria dan wanita. ${ }^{11}$ Bansai et al., (2007) juga melaporkan bahwa trigliserida sebagai faktor risiko stroke iskemik hanya pada wanita yang menunjukkan nilai bermakna dan pada laki-laki kurang bermakna. ${ }^{28}$

\section{Hubungan kolesterol total dengan lama rawatan pasien}

Hasil uji statistik diperoleh nilai signifikansi ( $p$ value) sebesar $0,001(p<0,01)$ yang berarti $\mathrm{H}_{0}$ ditolak sehingga terdapat hubungan antara kadar kolesterol total dengan lama rawatan pasien stroke iskemik di BLUD RSU Cut Meutia Kabupaten Aceh Utara.

Peningkatan kadar kolesterol total dalam darah akan menyebabkan terjadinya akumulasi LDL pada tunica intima. Timbunan LDL akan dioksidasi karena pembuluh darah mengalami jejas (stres), kemudian terjadilah stres oksidatif. Stres oksidatif akan menimbulkan reaksi inflamasi. Sel-sel radang menghasilkan Monocyte Chemotactic Factor (MCF) sehingga monosit akan masuk sampai ke dasar tunica intima dan kemudian berubah menjadi makrofag. Makrofag bermigrasi sambil memfagosit LDL yang tertimbun dan terbentuklah sel sabun. ${ }^{10}$

Selain migrasi makrofag, terjadi migrasi Smooth Muscle Cells (SMCs) dari tunica media vasa menuju tunica intima yang menimbulkan akumulasi matriks ekstra seluler (serabut-serabut hialin, kolagen, elastin, dan fibrosa) yang diproduksi oleh SMCs. Adanya akumulasi matriks ekstra seluler menimbulkan kalsifikasi dan fibrosis plak ateroma sehingga elastisitas dan diameter pembuluh darah berkurang. Deposit lemak atau plak akan merusak dinding arteri sehingga terjadi penyempitan dan pengerasan yang menyebabkan berkurangnya fungsi pada jaringan yang disuplai oleh arteri tersebut. ${ }^{29}$

Kadar kolesterol yang tinggi merupakan faktor risiko terjadinya penyakit kardiovaskular dan serebrovaskular. Studi observasional dan epidemiologi menunjukkan bahwa tidak ada hubungan yang pasti antara insidensi stroke dengan kadar kolesterol darah. ${ }^{30}$ Hubungan antara kolesterol dan risiko stroke merupakan hal yang kompleks, hiperlipidemia memiliki hubungan positif kuat dengan stroke iskemik. Kadar Kolesterol darah yang tinggi merupakan salah satu faktor penyebab terjadinya jejas endotel selain karena hipertensi. Jejas endotel merupakan proses awal terjadinya aterosklerosis yang kemudian akan menjadi trombus. Trombus merupakan penyebab tersering dari stroke iskemik. ${ }^{31}$

Kolesterol total merupakan jumlah dari LDL, HDL dan trigliserida yang terdapat di dalam darah. Hasil Penelitian ini didapatkan bahwa terdapat hubungan antara LDL dan HDL dengan lama rawatan pasien stroke iskemik di BLUD RSU Cut Meutia sehingga pada penelitian ini juga didapatkan hubungan antara kolesterol total dengan lama rawatan pasien stroke iskemik.

\section{Kesimpulan}

1. Rata-rata kadar profil lipid pasien stroke iskemik di BLUD RSU Cut Meutia yaitu LDL 155,70 mg/dL, HDL 44,04 mg/dL, trigliserida $152,13 \mathrm{mg} / \mathrm{dL}$ dan kolesterol 
total $44,04 \mathrm{mg} / \mathrm{dL}$.

2. Terdapat hubungan antara kadar LDL, HDL dan kolesterol total dengan lama rawatan pasien stroke iskemik di BLUD RSU Cut Meutia Kabupaten Aceh Utara.

3. Tidak terdapat hubungan antara kadar trigliserida dengan lama rawatan pasien stroke iskemik di BLUD RSU Cut Meutia Kabupaten Aceh Utara.

\section{Saran}

1. Diharapkan BLUD RSU Cut Meutia untuk melengkapi dokumen administrasi pasien yang terdapat di rekam medik agar memudahkan peneliti selanjutnya sehingga jumlah sampel yang digunakan lebih banyak.

2. Perlu penelitian lebih lanjut dengan cakupan wilayah yang lebih luas sehingga dapat mendukung kesimpulan yang didapat dari penelitian ini.

3. Tenaga kesehatan diharapkan dapat memberikan edukasi kepada masyarakat yang memiliki risiko tinggi untuk melakukan pengontrolan serta diet untuk mencegah terjadinya stroke.

\section{Daftar Pustaka}

1. Sacco RL, Kasner SE, Broderick JP, Caplan LR, Culebras A, Elkind MSV, George MG, Hamdan AD, Higashida RT, Hoh BL, Janis, S. 2013. An updated definition of stroke for the 21st century. Journal of the American Medical Association 2013: 285(21):2729-2735.

2. Go AS, Mozaffarian D, Roger VL, Benjamin EJ, Berry JD, Borden WB, Turner MB. 2013. Heart disease and stroke statistics 2013 Update. A Report From the American Heart Association.

3. Meschia JF, Bushnell C, Boden-albala B, Braun LT, Bravata DM, Chaturvedi S, Wilson JA. 2014. AHA guidelines for the primary prevention of stroke.
4. Furie KL, Kasner SE, Adams RJ, Albers GW, Bush RL, Fagan SC, Turan TN. 2011. AHA guidelines for the prevention of stroke in patients with stroke or transient ischemic Attack: 227.

5. Suryantika, F. 2013. Gambaran fungsi kognitif pasien stroke di IRNA di RSUP Sanglah Denpasar tahun 2013. Artikel elektronik 2013 [cited 2015 August 14]. Available from: URL: http://www.academia.edu.

6. Departemen Kesehatan RI. Riset kesehatan dasar 2013. Jakarta: Badan Penelitian dan Pengembangan Kesehatan Kementerian Kesehatan RI, 2013.

7. Black J, Hawks JH. Medical surgical nursing clinical management for positive outcomes. $8^{\text {th }}$ edition. St. Louis, Missouri: Saunders Elsevier, 2009.

8. Edi V, Anggraini H, Sukeksi A. Hubungan profil lipid darah pada penderita stroke iskemik. Skripsi. Semarang: Fakultas Kedokteran Universitas Muhammadiyah, 2014.

9. Azmi E. Gambaran kadar kolesterol HDL dan tekanan darah pasien stroke yang dirawat di Bagian Saraf RSUD Arifin Achmad Provinsi Riau. Skripsi. Riau: Fakultas Kedokteran Universitas Riau, 2014.

10. Gofir, A. Management stroke: evidence based medicine. Yogyakarta: Pustaka Cendekia Press, 2009.

11. Varbo A, Nordestgaard BG, Hansen AT, Schnohr P, Jensen GB, Benn M. Nonfasting triglycerides, cholesterol, and ischemic stroke in the general population. Artikel elektronik 2011 [cited 2015 June 10]. Available from URL:

http://onlinelibrary.wiley.com/doi/10. 1002/ana.22384/full.

12. Newman GC, Bang H, Hussain SI, Toole, JF. Association of diabetes, homocysteine, and HDL with cognition 
and disability after stroke. Artikel elektronik 2007 [cited 2015 November 14]. Available from URL; http://www.neurology.org/content/69 /22/2054.short

13. Thaib P. Hubungan antara kadar LDL darah pada stroke iskemik fase akut dengan lama perawatan pasien pulang hidup dan pulang meninggal. Skripsi. Semarang: Fakultas Kedokteran Universitas Diponegoro, 2008.

14. Wahjoepramono EJ. Stroke: tata laksana fase akut. Jakarta: Universitas Pelita Harapan, 2005.

15. Heart and Stroke Foundation. A perfect storm of heart disease looming on our horizon. Artikel elektronik 2010 [cited 2016 February 15]. Available from URL: http:// www.heartandstroke.com.

16. Yanis H. Pola kadar glukosa darah pada stroke akut. Tesis. Semarang: Program Pendidikan Pasca Sarjana Universitas Diponegoro, 2004.

17. Agustina E. Prevalensi stroke iskemik pada pasien rawat inap di RSUP Fatmawati Jakarta Selatan pada tahun 2008. Skripsi. Jakarta: Fakultas Kedokteran dan Ilmu Kesehatan Universitas Islam Negeri Syarif Hidayatullah, 2009.

18. Nastiti D. Gambaran faktor risiko kejadian stroke pada paien stroke rawat inap di Rumah Sakit Krakatau Medika tahun 2011. Skripsi. Jakarta: Fakultas Kesehatan Masyarakat Universitas Indonesia, 2012.

19. Japardi I. Patofisiologi stroke infark akibat tromboemboli. Medan: Fakultas Kedokteran Universitas Sumatra Utara, 2002.

20. Khomsan A. Dampak terapi estrogen pada wanita menopause. Artikel elektronik 2002 [cited 2016 January 20]. Available from URL: http://kolom.pacific.net.id/ind/index2. php?option $=$ com_content\&do_pdf $=1 \& \mathrm{i}$ $\mathrm{d}=158$.
21. Handayani F. Angka kejadian serangan stroke pada wanita lebih rendah daripada laki-laki. Jurnal Keperawatan Medikal Bedah 2013; 1(1): 75-79.

22. Soeharto I. Serangan jantung dan stroke hubungannya dengan lemak dan kolesterol. Jakarta: PT Gramedia Pustaka Utama, 2004.

23. Ois A, Godia EC, Conde JJ, Gomis M, Campello AR, Rodríguez JEM. Early arterial study in the prediction of mortality after acute ischemic stroke, 2007.

24. Sohail A, Khatri IA, Mehboob N, Sanossian. Effect of dyslipidemia ob severity and outcome of stroke using mRS scores in Nothern Pakistani population. RMJ 2013; 38: 345-350.

25. Saribanon, S. Hubungan kadar LDL kolesterol dengan mortalitas pasien stroke iskemik fase akut di RSUD DR. Moewardi Surakarta. Skripsi. Solo: Fakultas Kedokteran Universitas Sebelas Maret, 2011.

26. Bull, E. Kolesterol. Jakarta: Erlangga, 2007.

27. Freiberg J, Hansen A, Jensen JS, Nordestgaard BG. Nonfasting triglycerides and risk of ischemic stroke in the general population. Journal of the American Medical Association 2008: 18:2142-2152.

28. Bansal S, Buring J, Rifai N, Mora S, Sacks F, Ridker P. Fasting compared with nonfasting triglycerides and risk of cardiovascular events in women. Journal of the American Medical Association 2007: 298(3):309-316.

29. Price SA, Wilson LM. Patofisiologi: Konsep klinis proses-proses penyakit edisi 6, Jakarta: EGC, 2005.

30. Cheung BM, Lauder IJ, Lau CP, Kumana CR. Meta-analysis of large randomized controlled trials to evaluate the impact of statins on cardiovascular outcomes. Br J Colin Pharmacol 2004;57:640-651. 
31. Knuiman MW, Vu HTV. Risk factors for stroke mortality in men and women: the Busselton Study. Journal Cardiovascular Risk volume 1996; 3: 447- 452. 